\title{
Amorphous Calcium Salt Composition Bioavailability Evaluation in Chickens
}

\author{
D. Babarykin ${ }^{1}$, M. Mutalova1, G. Smirnova ${ }^{1,2}$, S. Vasiljeva², G. Krumina1, N. Basova ${ }^{2}$, \\ V. Agejchenko1, R. Simanis ${ }^{3}$
}

${ }^{1}$ Institute of Innovative Biomedical Technology Ltd., Riga, Latvia

${ }^{2}$ Institute of Biology of the University of Latvia, Salaspils, Latvia

${ }^{3}$ Riga Stradins University, Riga, Latvia

Email: *dmitry.b@parks.lv

How to cite this paper: Babarykin, D., Mutalova, M., Smirnova, G., Vasiljeva, S., Krumina, G., Basova, N., Agejchenko, V. and Simanis, R. (2019) Amorphous Calcium Salt Composition Bioavailability Evaluation in Chickens. Journal of Biosciences and Medicines, 7, 15-25.

https://doi.org/10.4236/jbm.2019.72002

Received: December 13, 2018

Accepted: January 20, 2019

Published: January 23, 2019

Copyright $\odot 2019$ by author(s) and Scientific Research Publishing Inc. This work is licensed under the Creative Commons Attribution International License (CC BY 4.0).

http://creativecommons.org/licenses/by/4.0/

\begin{abstract}
Despite the market saturation with a wide range of calcium preparations in dietary supplements as well as in pharmaceuticals, calcium product safety and efficacy remain an item for further optimization. Bones and teeth mainly consist of calcium phosphate, but tablets and capsules are predominantly produced from calcium carbonate. On the other hand, in human food $\mathrm{Ca}^{2+}$ is bound with a lot of anions-carbonates, sulphates, chlorides, phosphates, citrates, oxalates etc. It seems that traditional calcium formulations due its low bioavailability cannot provide all spectra of biological calcium-dependant effects and dietary calcium might be safer and more effective than traditional calcium supplements and medicines. To increase calcium salt efficacy a new formulation of calcium salts has been developed. It is a mixture (water suspension) of amorphous calcium carbonate, citrate, hydrocarbonate, as well as magnesium hydrocarbonate and hydrocitrate as stabilizers. The capacity of a cockerel's duodenal mucosa to absorb $\mathrm{Ca}^{2+}$ after peroral ingestion of the mentioned composition in vivo was as much as $126 \%$ higher in comparison with $\mathrm{CaCO}_{3}$ suspension intake. Vitamin $\mathrm{D}_{3}$ enhanced the amorphous antirachitic activity of calcium salts. The aim of the study was to compare original amorphous calcium salt composition bioavailability with Ca salts most often in food and medicines, as well as to evaluate the antirachitic activity of the mentioned composition in combination with vitamin $\mathrm{D}_{3}$ in chickens.
\end{abstract}

\section{Keywords}

Calcium Absorption, Amorphous Calcium, Experimental Rickets, Chicken

\section{Introduction}

Due to the dependence of a huge number of the organism's essential biochemical 
and physiological processes of calcium (Ca), the complex system of Ca metabolism regulation in mammals has been developed during evolution. This mechanism regulates $\mathrm{Ca}$ intestinal absorption, supporting the constant cations blood concentration in any physiological periods. In the case of inadequate $\mathrm{Ca}$ absorption from the gastrointestinal tract, stabile calcemia is supported on the account of the destruction of the skeleton due to hyperactivity of the parathyroid glands [1].

Despite the wide prevalence of calcium minerals in nature, there is a global problem of Ca deficiency for livestock and humans. Of great importance is not only $\mathrm{Ca}$ content in the diet, but also Ca bioavailability. Inadequate consumption of dairy products, excessive drinking water purification from minerals and growing popularity of ortho-phosphate containing light drinks are tending toward Ca deficiency [2]. But medicinal technological progress, prolongation of human life, and the increase of the number of patients with earlier incurable gastroenterological and endocrinological diseases promote the prevalence of secondary Ca deficiency.

Intestinal $\mathrm{Ca}$ absorption occurs through the transcellular and paracellular pathways. The first route comprises the entrance of $\mathrm{Ca}$ across the brush border membranes (BBM) of enterocytes through special epithelial Ca channels; $\mathrm{Ca}$ movement from BBM to basolateral membranes by binding proteins with high $\mathrm{Ca}$ affinity (as calbindin) and $\mathrm{Ca}$ extrusion into the blood. Plasma membrane Ca-ATPase and a sodium calcium exchanger are involved in the exit of $\mathrm{Ca}$ from enterocytes. Paracellular $\mathrm{Ca}$ transport includes the movement of the ions through transmembranes of tight junction structures and depends on the electrochemical gradient of the intestinal epithelium. There is evidence of crosstalk between both pathways in intestinal Ca transport. Under the impact of pathogenic factors (oxidative stress) due to the decrease in expression of several molecules of both pathways, Ca absorption is inhibited [3]. Vitamin D, more precisely, its active metabolite $1.25(\mathrm{OH})_{2} \mathrm{D}_{3}$ or calcitriol, which is the principal promoter of $\mathrm{Ca}$ intestinal absorption [4], acts in the opposite direction-increases gene and protein expression, involved in both pathways.

The presence of two pathways of intestinal $\mathrm{Ca}$ absorption has an important biological meaning. The paracellular pathway provides a passive basic flow of $\mathrm{Ca}$ into the organism's internal environment. The transcellular pathway is active, energy dependent and provides "fine" Ca absorption regulation, its adaptation to the mineral content in the diet, bioavailability, organism physiological status etc. Wherein the effects on $\mathrm{Ca}$ intestinal absorption of other hormones-thyroid, parathyroid, growth hormones, estrogens, prolactin-are mediated via calcitriol synthesis [5].

The above algorithm of $\mathrm{Ca}$ absorption regulation implies an important practical conclusion. In the case of $\mathrm{Ca}$ deficiency, it is rational to stimulate both $\mathrm{Ca}$ intestinal transport pathways. So, the combination of Ca preparations and vitamin D became the "golden standard" for metabolic bone disease prevention and treatment [6] [7]. 
Thus, the main factors which determine $\mathrm{Ca}$ intestinal absorption are vitamin $\mathrm{D}$ status, Ca content in the diet as well as mineral bioavailability. In general, Ca bioavailability depends on the corresponding salt solubility, capability to provide absorbable $\mathrm{Ca}$ ions. $\mathrm{Ca}$ salts of most frequent use, carbonate, citrate, pidolate, dobesilate, gluconate, phosphate and lactate, contribute different quantities of elementary $\mathrm{Ca}$ [8]. The percentage content of $\mathrm{Ca}$ is minimal for lactate and gluconate. Ca absorption from calcium citrate is consistently significantly higher than from calcium carbonate by $27.2 \%$ on an empty stomach, and by $21.6 \%$ with meals [9], but calcium carbonate has better cost effectiveness [10].

A lot of natural compounds modulate Ca salt solubility. Thus, sodium gluconate can increase the solubility of calcium lactate [11]. Amino acids and bile components reduce $\mathrm{Ca}$ salt precipitation in the intestine, increasing ion bioavailability [12]. It should be noted that $\mathrm{Ca}$ from dairy products as well as high-calcium mineral waters have high absorbability [13].

It seems the search for new Ca containing substances with high bioavailability has reached a certain impasse. Food does not contain pure $\mathrm{Ca}$ compounds but is the mixture of a lot of chemicals. On the other hand, Ca from salt mixtures has higher bioavailability in comparison with mono salts. In addition, food Ca toxicity is less than that of pure Ca chemicals at the same dosage [14]. This allows us to conclude that to develop highly bioavailable Ca compounds we should return to nature. From this point of view, amorphous Ca salts seem promising.

Amorphous calcium carbonate (ACC) has the highest reported specific surface area of all current forms of calcium carbonate [15]. Although unstable under ambient conditions, ACC is surprisingly widespread in biology either as a precursor phase, which later transforms into more crystalline forms, or as a stabilized phase sometimes coexisting with crystalline polymorphs [16]. Biogenic ACC often contains stabilizers to avoid or delay unwanted crystallization. Magnesium is commonly present as one of the stabilizing agents [17]. A study on rats revealed that $\mathrm{Ca}$ absorption from ACC preparations was up to $40 \%$ higher than from calcium carbonate [18]. Recent technology allows the synthesis of a stable amorphous calcium salt, containing different anions. The method of preparation of the composition of amorphous $\mathrm{Ca}$ and $\mathrm{Mg}$ salts has been developed recently [19]. Water and inorganic additives: calcium carbonate, calcium citrate, calcium hydrocitrate, magnesium citrate were used to stabilize the ACC.

The aim of the study was to compare original amorphous calcium salt composition bioavailability with Ca salts most often in food and medicines, as well as to evaluate the antirachitic activity of the mentioned composition in combination with vitamin $\mathrm{D}_{3}$ in chickens.

\section{Materials and Methods}

\subsection{Ethics Statement}

All experimental procedures were approved by the local Animal Ethics Committee. 


\subsection{Amorphous Calcium Salt Composition (ACaSC)}

ACaSC was prepared using our previously developed method [19] [20]. ACaSC is a thick white suspension and contains calcium carbonate, calcium citrate, calcium hydrocitrate and magnesium citrate. The total calcium content in the mixture was $50 \mathrm{mg} / \mathrm{g}$ of calcium and magnesium- $0.64 \mathrm{mg} / \mathrm{g}$. ACaSC $\mathrm{pH}$ (diluted with water 1:1) is 7.53 .

\subsection{Experimental Design and Animals}

Lohmann Brown cockerels were used for the laboratory investigations. Chickens were delivered from the Latvian poultry company "Balticovo Ltd." and housed in cage units with free access to food and water. The animals were fed a wheat-barley full-fed diet, containing all necessary nutrients. Calcium content in the diet was $7.75 \mathrm{mg} / \mathrm{kg}$.

Two experiments have been done to study:

1) Dependence of $\mathrm{Ca}$ absorption in chicken duodenum on the chemical composition of ingested Ca salt, its dosage and exposition time;

2) Antirachitic efficacy of amorphous salt composition (ACaSC) with and without cholecalciferol (vitamin $\mathrm{D}_{3}$ ) supplementation.

At the end of the experiment the cockerels were weighted and sacrificed by decapitation, in accordance with the recommendations of the European Convention [21] for the euthanasia of experimental animals.

Experiment 1. 30-day-old chickens with a body weight of $289.3 \pm 29.5 \mathrm{~g}$ were randomized in 7 experimental groups of 7 heads each. Ca absorption in chicken duodenum was studied in vivo. 18 hours before the experiment the food was removed from the cages; drinking water was available. Different $\mathrm{Ca}$ salts-carbonate, chloride (as hexahydrate) and a tested amorphous Ca composition suspended (diluted) in $2 \mathrm{ml}$ of distilled water were ingested per os 45 or 60 min before decapitation. The amount of administrated Ca with all kinds of salts was 1.2 or $2.4 \mathrm{mg}$. The chickens of control group received drinking water only.

At the end of the exposition period, vein ( $v$. jugularis) blood sampling was done. The chickens were decapitated, the liver and isolated intestine segments removed. Duodenum content was drained into a test-tube; segments were rinsed with $1 \mathrm{ml}$ of $154 \mathrm{mM} \mathrm{NaCl}$ and put into a separate test-tube. The duodenum (intestinal content and mucosa) was analyzed for Ca content. The amount of $\mathrm{Ca}$ absorbed was calculated as the difference between Ca content just after ingestion infusion of the tested compounds and after the exposition period and expressed as $\mathrm{nmol} / \mathrm{g}$ tissue.

Experiment 2. 2-day-old Lohmann Brown cockerels were used in the study. The birds were weighed and randomized in 6 groups $(n=7)$. The chickens were fed ad libitum vitamin D-free feed, containing: corn flour- $40 \%$, barley-30\%, soybean meal- $15 \%$, casein- $10 \%$, fodder yeast- $3 \%$, dicalcium phosphate- $0.5 \%$, chalk- $0.25 \%$, salt $-0.5 \%$, Ca content $-0.81 \%$, phosphorus- $0.64 \%$ (basic ration). The 
control group was provided the mentioned diet (control) but enriched with cholecalciferol (400 IU/kg). The experimental algorithm is as follows (Table 1).

At the age of 4 weeks venous blood sampling was done, the chickens were decapitated, the parathyroid glands were extirpated and weighted, the femurs collected for subsequent analysis. Parathyroid relative weight was calculated as a gland and body weight ratio. In blood serum calcium, phosphorus concentration and alkaline phosphatase activity were measured. The gravity of defatted and dried femur was measured; also, calcium and phosphorus content in bone was analyzed.

Three days before the decapitation of the birds, the daily balance of minerals in the chickens' bodies was evaluated. For 3 days, the food eaten every $24 \mathrm{~h}$ as well as the birds' litter were controlled (weighted, dried and analyzed for Ca content).

\subsection{Laboratory Determinations}

At the end of the experiment, $\mathrm{Fe}, \mathrm{Mg}$ and $\mathrm{Ca}$ concentrations in organs and tissues were estimated using a flame atomic absorption spectrophotometer (Perkin-Elmer, model AAnalyst 700) [22]. Duodenal mucosa were homogenized in a solution of ice-cold tris-buffer ( $\mathrm{pH}$ 7.4) using a glass homogenizer and a motor-driven Teflon pestle at $3000 \mathrm{rpm}$ for $1 \mathrm{~min}$ to yield a $20 \%(\mathrm{w} / \mathrm{v})$ homogenate. Proteins were denatured with trichloroacetic acid (120 g/l) and removed by centrifugation for $10 \mathrm{~min}$ at $600 \mathrm{~g}$.

The liver samples were dried at $1050 \mathrm{C}$ to constant weight, ashed in a muffle furnace at $6500 \mathrm{C}$, and subsequently dissolved in $6 \mathrm{~N}-\mathrm{HCl}$.

Blood serum was analyzed for $\mathrm{Fe}, \mathrm{Mg}$, $\mathrm{Ca}$ and alkaline phosphatase performed on ILAB 300+ analyzer (Instrumentation Laboratory, USA).

Table 1. Calcium salt antirachitic activity study in chickens.

\begin{tabular}{|c|c|}
\hline Experimental group & Characteristic of group \\
\hline 1) Control & Basic ration + vitamin $\mathrm{D}_{3}$ \\
\hline 2) Rickets & Basic ration (vitamin $\mathrm{D}_{3}$ free) \\
\hline 3) Basic ration $+\mathrm{CaCO}_{3}$ & $\begin{array}{l}\text { Basic ration (vitamin } \mathrm{D}_{3} \text { free); starting from the age of } \\
14 \text { days the chickens received per os calcium } \\
\text { carbonate for two weeks }\left(\mathrm{Ca}^{2+} 5 \mathrm{mg} / \text { day) }\right.\end{array}$ \\
\hline 4) Basic ration $+\mathrm{CaCO}_{3}+\mathrm{D}_{3}$ & $\begin{array}{l}\text { Basic ration (vitamin } \mathrm{D}_{3} \text { free); starting from the age of } 14 \text { days } \\
\text { the chickens received per os calcium carbonate for two weeks } \\
\left(\mathrm{Ca}^{2+} 5 \mathrm{mg} / \text { day) and cholecalciferol } 0.25 \mu \mathrm{g} / \text { day }\right.\end{array}$ \\
\hline 5) Basic ration $+\mathrm{ACaSC}^{*}$ & $\begin{array}{l}\text { Basic ration (vitamin } \mathrm{D}_{3} \text { free); starting from the age of } \\
14 \text { days age the chickens received per os amorphous } \\
\text { calcium salts for two weeks }\left(\mathrm{Ca}^{2+} 5 \mathrm{mg} / \text { day) }\right.\end{array}$ \\
\hline 6) Basic ration $+\mathrm{ACaSC}+\mathrm{D}_{3}$ & $\begin{array}{l}\text { Basic (vitamin } \mathrm{D}_{3} \text { free) ration; starting from the age of } 14 \text { days } \\
\text { the chickens received per os amorphous calcium salts for two } \\
\text { weeks }\left(\mathrm{Ca}^{2+} 5 \mathrm{mg} / \text { day) and cholecalciferol } 0.25 \mu \mathrm{g} / \text { day }\right.\end{array}$ \\
\hline
\end{tabular}

*Amorphous calcium salt composition contains calcium carbonate, calcium citrate, calcium hydrocitrate, magnesium citrate. 


\subsection{Statistical Analysis}

All statistics were performed using the software Statistica 7. Results of investigated parameters are presented as means \pm SE. Multiple group comparison was done using one-way ANOVA and Post-hoc Tukey HSD test.

\section{Results and Discussion}

The aim of the first experiment was to compare the impact of different ingested Ca salts on Ca content in duodenal mucosa as well as in blood serum and in the liver.

ACaSC specific activity was compared with Ca chloride, which is characterized by high Ca bioavailability, as well as with calcium carbonate - the most commonly used $\mathrm{Ca}$ salt in food and medicines but having low solubility and bioavailability. In dose $1.2 \mathrm{mg} \mathrm{Ca}$ all tested preparations did not induce statistically significant changes neither in the duodenal mucosa, nor the blood serum (Table 2 and Table 3). However, induced Ca accumulation in the liver was found by all formulations, but it was the same in all groups.

Table 2. Mineral content in chickens duodenal mucosa after peroral ingestion of amorphous calcium salt composition (ACaSC) and comparable calcium salts (ingesting period $60 \mathrm{~min})$.

\begin{tabular}{lcccc}
\hline \multirow{2}{*}{$\begin{array}{c}\text { Ca formulation in } \\
\text { experimental group }\end{array}$} & Ca dose, $\mathrm{mg}$ & \multicolumn{3}{c}{ Mineral content in duodenal mucosa, $\mu \mathrm{g} / \mathrm{g}$} \\
\cline { 3 - 5 } & 0 & $\mathrm{Ca}$ & $\mathrm{Fe}$ & $\mathrm{Mg}$ \\
\hline 1) Control & 1.2 & $0.53 \pm 0.13^{\mathrm{c} *}$ & $0.11 \pm 0.03^{\mathrm{a}}$ & $0.55 \pm 0.10^{\mathrm{b}}$ \\
2) Calcium chloride & 1.2 & $0.68 \pm 0.20^{\mathrm{bc}}$ & $0.12 \pm 0.03^{\mathrm{a}}$ & $0.60 \pm 0.13^{\mathrm{ab}}$ \\
3) Calcium carbonate & 1.2 & $0.73 \pm 0.18^{\mathrm{bc}}$ & $0.09 \pm 0.04^{\mathrm{a}}$ & $0.89 \pm 0.16^{\mathrm{a}}$ \\
4) ACaSC & 2.4 & $0.98 \pm 0.25^{\mathrm{bc}}$ & $0.09 \pm 0.01^{\mathrm{a}}$ & $0.58 \pm 0.25^{\mathrm{ab}}$ \\
5) Calcium chloride & 2.4 & $1.08 \pm 0.22^{\mathrm{b}}$ & $0.11 \pm 0.04^{\mathrm{a}}$ & $0.70 \pm 0.34^{\mathrm{ab}}$ \\
6) Calcium carbonate & 2.4 & $1.63 \pm 0.26^{\mathrm{a}}$ & $0.09 \pm 0.01^{\mathrm{a}}$ & $0.56 \pm 0.18^{\mathrm{ab}}$ \\
7) ACaSC & & & &
\end{tabular}

${ }^{\star}$ Statistically different or similar within column according to Post-hoc Tukey HSD test $(\mathrm{p}<0.05)$; ${ }^{* *}$ Amorphous calcium salt composition contains calcium carbonate, calcium citrate, calcium hydrocitrate, magnesium citrate.

Table 3. Mineral content in chicken liver and blood serum after peroral ingestion of amorphous calcium salts composition (ACaSC) and comparable calcium salts (ingesting period $45 \mathrm{~min}$ ).

\begin{tabular}{lccccc}
\hline \multirow{2}{*}{$\begin{array}{c}\text { Ca formulation in } \\
\text { experimental group }\end{array}$} & Ca dose, & Ca content in & \multicolumn{3}{c}{ Mineral content in blood serum } \\
\cline { 4 - 6 } & liver, $\mu \mathrm{g} / \mathrm{g}$ & $\mathrm{Ca}, \mathrm{mmol} / \mathrm{L}$ & $\mathrm{Mg}, \mathrm{mmol} / \mathrm{L}$ & $\mathrm{Fe}, \mathrm{mg} / \mathrm{L}$ \\
\hline 1) Control & 0 & $0.021 \pm 0.011^{\mathrm{b} *}$ & $2.82 \pm 0.06^{\mathrm{a}}$ & $0.67 \pm 0.16^{\mathrm{b}}$ & $2.08 \pm 0.06^{\mathrm{ab}}$ \\
2) Calcium chloride & 1.2 & $0.163 \pm 0.063^{\mathrm{a}}$ & $2.77 \pm 0.13^{\mathrm{a}}$ & $0.82 \pm 0.11^{\mathrm{ab}}$ & $2.12 \pm 0.06^{\mathrm{a}}$ \\
3) Calcium carbonate & 1.2 & $0.150 \pm 0.016^{\mathrm{a}}$ & $2.89 \pm 0.07^{\mathrm{a}}$ & $0.69 \pm 0.08^{\mathrm{b}}$ & $1.98 \pm 0.10^{\mathrm{bc}}$ \\
4) ACaSC & 1.2 & $0.144 \pm 0.026^{\mathrm{a}}$ & $2.81 \pm 0.11^{\mathrm{a}}$ & $0.70 \pm 0.05^{\mathrm{b}}$ & $2.03 \pm 0.05^{\mathrm{b}}$ \\
5) Calcium chloride & 2.4 & $0.130 \pm 0.028^{\mathrm{a}}$ & $3.02 \pm 0.17^{\mathrm{a}}$ & $0.81 \pm 0.20^{\mathrm{ab}}$ & $2.15 \pm 0.08^{\mathrm{a}}$ \\
6) Calcium carbonate & 2.4 & $0.146 \pm 0.024^{\mathrm{a}}$ & $2.96 \pm 0.11^{\mathrm{a}}$ & $0.96 \pm 0.23^{\mathrm{ab}}$ & $1.82 \pm 0.08^{\mathrm{c}}$ \\
7) ACaSC & 2.4 & $0.164 \pm 0.022^{\mathrm{a}}$ & $2.98 \pm 0.10^{\mathrm{a}}$ & $1.00 \pm 0.13^{\mathrm{a}}$ & $2.18 \pm 0.05^{\mathrm{a}}$ \\
\hline
\end{tabular}

${ }^{*}$ Statistically different or similar within column according to Post-hoc Tukey HSD test $(\mathrm{p}<0.05)$;

${ }^{*}$ Amorphous calcium salt composition. 
At a dose of $2.4 \mathrm{mg} \mathrm{Ca}$, the ingestion of $\mathrm{Ca}$ salts caused an increase of $\mathrm{Ca}$ content in intestinal mucosa. The effect of ingested $\mathrm{Ca}$ salts- $\mathrm{Ca}$ chloride, $\mathrm{Ca}$ carbonate and ACaSC was 85\%, 103\% and 207\% stronger in comparison with control, respectively. Taking into account the fact, that $\mathrm{Ca}$ absorption by duodenal mucosa is the best indicator of intestinal absorption of ions [1] we can conclude that ACaSC bioavailability exceed calcium chloride and calcium carbonate by $66 \%$ and $51 \%$, respectively.

Ca content in the liver of animals of the 7th group did not differ from that of groups 2 - 4, the calcemia level tended to increase, but not significantly. Attention is drawn to the fact of the decrease of iron concentration in blood serum in animals of group 6 (received calcium carbonate), although this fact was not observed in groups 5 (calcium chloride) and 7 (ACaSC) (Table 1). The probable mechanism of such a phenomenon is a lumenal event: calcium carbonate with phosphates and iron ions form an insoluble complex, which decreases Fe bioavailability [23] and can cause iron deficiency anaemia [24]. From the point of view of practical application, ACaSC has an advantage in comparison with calcium chloride, which is not indicated for long term use.

In the second experiment antirachitic efficacy of ACaSC per os, as well as in combination with vitamin $\mathrm{D}_{3}$, was tested. At the age of 4 weeks the rachitic chickens' body weight was $54 \%$ of the control. The birds had an untidy appearance, a soft and deformed beak. Hypocalcemia and hyposphatemia were detected in the blood serum, the activity of alkaline phosphatase increased more than 2.5 times; hyperplasia of parathyroid glands was found: its relative weight exceeded the control 10 times (Table 4). The ash content in the femur was significantly less in comparison with the control (Table 5). This is the result of impaired bone mineralization due to primary calcium and vitamin deficiency as well as secondary hyperparathyroidism [1].

Under the influence of diet enrichment with calcium carbonate manifestations of rachitic in Group 3 weakened (increased blood serum $\mathrm{Ca}$, diminished alkaline

Table 4. Impact of calcium preparations and vitamin $\mathrm{D}_{3}$ peroral ingestion on biochemical indices of blood serum and parathyroid gland relative weight of chickens with rickets.

\begin{tabular}{|c|c|c|c|c|}
\hline \multirow[b]{2}{*}{ Experimental group } & \multicolumn{3}{|c|}{ Blood serum } & \multirow{2}{*}{$\begin{array}{l}\text { Parathyroid } \\
\text { gland } \\
\text { relative weight, } \\
\text { mg/100 g BW }\end{array}$} \\
\hline & $\mathrm{Ca}, \mathrm{mmol} / \mathrm{L}$ & $\mathrm{P}, \mathrm{mmol} / \mathrm{L}$ & $\begin{array}{c}\text { Alkaline } \\
\text { phosphatase, IU }\end{array}$ & \\
\hline 1) Control $\left(D_{3}\right)$ & $2.66 \pm 0.13^{a \star}$ & $1.52 \pm 0.07^{\mathrm{a}}$ & $14.2 \pm 2.18^{\mathrm{c}}$ & $0.53 \pm 0.10^{\mathrm{d}}$ \\
\hline 2) Rickets (basic ration) & $1.98 \pm 0.21^{\mathrm{c}}$ & $1.04 \pm 0.06^{\mathrm{c}}$ & $38.7 \pm 3.31^{\mathrm{a}}$ & $5.24 \pm 0.45^{\mathrm{a}}$ \\
\hline 3) Basic ration $+\mathrm{CaCO}_{3}$ & $2.12 \pm 0.08^{c}$ & $1.14 \pm 0.05^{\mathrm{c}}$ & $33.7 \pm 3.13^{\mathrm{a}}$ & $3.50 \pm 0.15^{\mathrm{b}}$ \\
\hline 4) $\mathrm{Basic}$ ration $+\mathrm{CaCO}_{3}+\mathrm{D}_{3}$ & $2.55 \pm 0.11^{\mathrm{ab}}$ & $1.54 \pm 0.09^{\mathrm{a}}$ & $17.3 \pm 1.59^{\mathrm{bc}}$ & $0.72 \pm 0.22^{\mathrm{cd}}$ \\
\hline 5) Basic ration $+\mathrm{ACaSC}^{\star *}$ & $2.34 \pm 0.11^{\mathrm{b}}$ & $1.30 \pm 0.05^{\mathrm{b}}$ & $21.1 \pm 2.37^{\mathrm{b}}$ & $0.80 \pm 0.12^{\mathrm{c}}$ \\
\hline 6) Basic ration $+\mathrm{ACaSC}+\mathrm{D}_{3}$ & $2.70 \pm 0.15^{\mathrm{a}}$ & $1.53 \pm 0.09^{\mathrm{a}}$ & $13.9 \pm 1.74^{\mathrm{c}}$ & $0.50 \pm 0.09^{d}$ \\
\hline
\end{tabular}

* Statistically different or similar within column according to Post-hoc Tukey HSD test $(\mathrm{p}<0.05)$;

${ }^{* *}$ Amorphous calcium salt composition. 
Table 5. The effect of calcium salts and vitamin $\mathrm{D}_{3}$ administration on body weight dynamic and content of ash in femur in chickens with rickets.

\begin{tabular}{lcccc}
\hline \multirow{2}{*}{ Experimental group } & \multicolumn{3}{c}{ Chicken body weight, $\mathbf{g}$} & Ash content \\
\cline { 2 - 4 } & $\mathbf{1}$ day & $\mathbf{1 4}$ day & $\mathbf{2 8 ~ d a y}$ & in the femur,\% \\
\hline 1) Control & $43.66 \pm 7.23^{\mathrm{a} *}$ & $158.3 \pm 10.9^{\mathrm{a}}$ & $337.5 \pm 31.7^{\mathrm{a}}$ & $48.93 \pm 3.84^{\mathrm{a}}$ \\
2) Ricket (basic ration) & $44.02 \pm 7.49^{\mathrm{a}}$ & $128.1 \pm 20.7^{\mathrm{ab}}$ & $180.5 \pm 10.9^{\mathrm{c}}$ & $22.85 \pm 2.35^{\mathrm{c}}$ \\
3) Basic ration $+\mathrm{CaCO}_{3}$ & $44.50 \pm 6.92^{\mathrm{a}}$ & $131.5 \pm 15.9^{\mathrm{ab}}$ & $219.1 \pm 16.2^{\mathrm{b}}$ & $29.86 \pm 1.76^{\mathrm{b}}$ \\
4) Basic ration $+\mathrm{CaCO}_{3}+\mathrm{D}_{3}$ & $43.46 \pm 8.44^{\mathrm{a}}$ & $138.5 \pm 7.07^{\mathrm{b}}$ & $302.4 \pm 17.7^{\mathrm{a}}$ & $46.85 \pm 4.47^{\mathrm{a}}$ \\
5) Basic ration $+\mathrm{ACaSC}^{* *}$ & $42.56 \pm 6.41^{\mathrm{a}}$ & $130.1 \pm 17.3^{\mathrm{ab}}$ & $236.1 \pm 12.0^{\mathrm{b}}$ & $30.77 \pm 1.42^{\mathrm{b}}$ \\
6) Basic ration $+\mathrm{ACaSC}+\mathrm{D}_{3}$ & $45.36 \pm 4.86^{\mathrm{a}}$ & $133.1 \pm 9.91^{\mathrm{b}}$ & $317.0 \pm 11.3^{\mathrm{a}}$ & $49.11 \pm 2.35^{\mathrm{a}}$ \\
\hline
\end{tabular}

${ }^{*}$ Statistically different or similar within column according to Post-hoc Tukey HSD test $(\mathrm{p}<0.05)$; **amorphous calcium salt composition.

phosphatase activity and parathyroid relative gland weight), but did not disappear completely. This was achieved using calcium carbonate in combination with cholecalciferol (Group 4). Based on body weight gain during the experiment, chicken groups may be arranged as follows: control/Group $1=$ Group $6>$ Group $4>$ Group 5 > Group $3>$ Group 2 (Table 5).

How did rachitic chickens (Group 5) respond to the administration of ACaSC, which has a higher than calcium carbonate bioavailability? All tested indices show, that ACaSC efficacy was better than for $\mathrm{CaCO}_{3}$ (Group 3), but worse than for $\mathrm{CaCO}_{3}$ in combination with vitamin $\mathrm{D}_{3}$ (Group 4). Complete normalization of all analyzed indices was achieved in chickens of Group 6, received ACaSC and vitamin $\mathrm{D}_{3}$. It seems logical, because vitamin $\mathrm{D}$ functions are not limited by influence on calcium intestinal absorption regulation [25].

In this experiment the different severity of rickets in bird groups is apparent: between the "classical" picture of D-avitaminosis and the healthy birds (Control). Ingestion of calcium carbonate, vitamin $\mathrm{D}_{3}$ and $\mathrm{ACaSC}$ to varying degrees normalized tested parameters. In general, the final outcomes, i.e. antirachitic efficacy, was practically the same in two groups receiving calcium carbonate + vitamin $\mathrm{D}_{3}$ (Group 4) and ACaSC + vitamin $\mathrm{D}_{3}$ (Group 6).

A calcium balance study did not identify significant differences between $\mathrm{Ca}$ accumulation only in the chickens of groups 4 and 6 (Table 6).

Ii case ACaSC was used without vitamin D, its specific activity exceeded $\mathrm{CaCO}_{3}$ in all tested physiological and biochemical parameters. This fact coincides with information, that in a double-blind randomized crossover clinical trial in postmenopausal women, it was shown that fractional $\mathrm{Ca}$ absorption of amorphous $\mathrm{Ca}$ was doubled on average compared to that of crystalline calcium carbonate [26]. The differences between $\mathrm{CaCO}_{3}$ and $\mathrm{ACaSC}$ biological activity in our experiment were "smoothed" by vitamin D.

Nevertheless, there is evidence of an amorphous calcium salt composition advantage in comparison with crystalline calcium carbonate. It was shown that ACaSC is more effective regarding parathyroid gland function suppression, not 
Table 6. The effect of calcium salts and vitamin $\mathrm{D}_{3}$ administration on chicken feed consumption and calcium daily balance.

\begin{tabular}{|c|c|c|}
\hline Experimental group & $\begin{array}{l}\text { Consumpted feed } \\
\text { quantity } \mathrm{g} / 100 \mathrm{~g} \text { BW/day }\end{array}$ & $\begin{array}{l}\text { Calcium balance* in } \\
\text { one day } \mathrm{mg} / \text { per one bird }\end{array}$ \\
\hline 1) Control & $9.9 \pm 2.1^{\mathrm{a} \star *}$ & \\
\hline 2) Ricket (basic ration) & $5.3 \pm 1.0^{\mathrm{b}}$ & (-) $24 \pm 3$ \\
\hline 3) $\mathrm{Basic}$ ration $+\mathrm{CaCO}_{3}$ & $6.4 \pm 1.3^{\mathrm{b}}$ & $(+) 31 \pm 5$ \\
\hline 4) Basic ration $+\mathrm{CaCO}_{3}+\mathrm{D}_{3}$ & $9.9 \pm 1.7^{\mathrm{a}}$ & $(+) 76 \pm 4$ \\
\hline 5) Basic ration + ACaSC & $6.9 \pm 1.3^{\mathrm{ab}}$ & $(+) 37 \pm 2$ \\
\hline 6) Basic ration $+\mathrm{ACaSC}+\mathrm{D}_{3}$ & $10.1 \pm 1.9^{\mathrm{a}}$ & $(+) 79 \pm 4$ \\
\hline
\end{tabular}

${ }^{*}(-)$ lost calcium quantity $(+)$ accumulated calcium quantity; ${ }^{*}$ Statistically different or similar within column according to Post-hoc Tukey HSD test $(\mathrm{p}<0.05)$.

impacting blood level of phosphates. In case ACaSC is used without vitamin D, its specific activity excels $\mathrm{CaCO}_{3}$ in all tested physiological and biochemical parameters. No less important is the ACaSC formulation: the fluid product is more suitable than calcium carbonate tablets and capsules for use by children and seniors.

The current paper contains only the initial part of the wider experiment's data. In the nearest future the information about combination's of ACaSC and vitamin D ricket's curative efficacy will be presented.

\section{Conclusion}

The studied composition of amorphous calcium salts seems prospective for new health food and pharmaceutical development. The product has a significantly higher bioavailability than calcium carbonate, suitable formulation for use by children and seniors. Combination with vitamin D increases ACaSC antirachitic effect. There is a reason to suppose that ACaSC together with some phytochemicals can provide significant osteoprotective activity in children and adults, including pregnant women.

\section{Conflicts of Interest}

The authors declare no competing interest concerning any commercial associations or patent licenses.

\section{References}

[1] Bauman, V. and Babarykin, D. (1993) Vitamins A and D in the Exchange of Divalent Cations. Sov.Sci. Rev. F. Physiol. Gen. Biol., 6, 1-53.

[2] Takeda, E., Sakamoto, K., Yokota, K., Shinohara, M., Taketani, Y., Morita, K. and Shibayama, M. (2002) Phosphorus Supply per Capita from Food in Japan between 1960 and 1995. Journal of Nutritional Science and Vitaminology, 48, 102-108.

[3] Diaz De Barboza, G., Guizzardi, S. and Tolosa De Talamoni, N. (2015) Molecular Aspects of Intestinal Calcium Absorption. World Journal of Gastroenterology, 21, 
7142-7154. https://doi.org/10.3748/wjg.v21.i23.7142

[4] Bauman, V. (1989) Biochemistry and Physiology of Vitamin D. Riga, Zinatne, 480 p. (In Russian)

[5] Masuyama, R. (2015) [Bone and Nutrition. Vitamin D Independent Calcium Absorption]. Clinical Calcium, 25, 1023-1028. (In Japanese)

[6] Matikainen, N. (2016) [Osteoporosis: A Clinical Perspective]. Duodecim, 132, 1051-1058. (In Finnish)

[7] Whiting, S.J., Kohrt, W.M., Warren, M.P., Kraenzlin, M.I. and Bonjour, J.P. (2016) Food Fortification for Bone Health in Adulthood: A Scoping Review. European Journal of Clinical Nutrition, 70, 1099-1105. https://doi.org/10.1038/ejcn.2016.42

[8] Sosa, M. and Bregni, C. (2003) Metabolism of the Calcium and Bioavailability of the Salts of Most Frequent Use. Bollettino Chimico Farmaceutico, 142, 28-33.

[9] Sakhaee, K., Bhuket, T., Adams-Huet, B. and Rao, D. (1999) Meta-Analysis of Calcium Bioavailability: A Comparison of Calcium Citrate with Calcium Carbonate. American Journal of Therapeutics, 6, 313-321. https://doi.org/10.1097/00045391-199911000-00005

[10] Heaney, R.P., Dowell, M.S., Bierman, J., Hale, C.A. and Bendich, A. (2001) Absorbability and Cost Effectiveness in Calcium Supplementation. Journal of the American College of Nutrition, 20, 239-246. https://doi.org/10.1080/07315724.2001.10719038

[11] Phadungath, C. and Metzger, L.E. (2011) Effect of Sodium Gluconate on the Solubility of Calcium Lactate. Journal of Dairy Science, 94, 4843-4849. https://doi.org/10.3168/jds.2011-4549

[12] Goss, S., Prushko, J. and Bogner, R. (2010) Factors Affecting Calcium Precipitation during Neutralisation in a Simulated Intestinal Environment. Journal of Pharmaceutical Sciences, 99, 4183-4191. https://doi.org/10.1002/jps.22131

[13] Heaney, R.P. (2006) Absorbability and Utility of Calcium in Mineral Waters. American Journal of Clinical Nutrition, 84, 371-374. https://doi.org/10.1093/ajcn/84.2.371

[14] Bristow, S.M., Gamble, G.D., Stewart, A., Kalluru, R., Horne A.M. and Reid, I.R. (2015) Acute Effects of Calcium Citrate with or without a Meal, Calcium-Fortified Juice and a Dairy Product Meal on Serum Calcium and Phosphate: A Randomised Cross-Over Trial. British Journal of Nutrition, 113, 1585-1594. https://doi.org/10.1017/S000711451500080X

[15] Sun, R., Zhang, P., Bajnóczi, É.G., Neagu, A., Tai, C.W., Persson, I., Strømme, M. and Cheung, O. (2018) Amorphous Calcium Carbonate Constructed from Nanoparticle Aggregates with Unprecedented Surface Area and Mesoporosity. ACS Applied Materials and Interfaces, 10, 21556-21564. https://doi.org/10.1021/acsami.8b03939

[16] Albéric, M., Bertinetti, L., Zou, Z., Fratzl, P., Habraken, W. and Politi, Y. (2018) The Crystallization of Amorphous Calcium Carbonate Is Kinetically Governed by Ion Impurities and Water. Advanced Science, 5, Article ID: 1701000. https://doi.org/10.1002/advs.201701000

[17] Jensen, A.C.S., Rodriguez, I., Habraken, W.J.E.M., Fratzl, P. and Bertinetti, L. (2018) Mobility of Hydrous Species in Amorphous Calcium/Magnesium Carbonates. Physical Chemistry Chemical Physics, 20, 19682-19688. https://doi.org/10.1039/C8CP01782D

[18] Meiron, O.E., Bar-David, E., Aflalo, E.D., Shechter, A., Stepensky, D., Berman, A. 
and Sagi, A. (2011) Solubility and Bioavailability of Stabilized Amorphous Calcium Carbonate. Journal of Bone and Mineral Research, 26, 364-372. https://doi.org/10.1002/jbmr.196

[19] Fattahov, A. and Razikulov, S. (2013) Composition for Oral Cavity Care. Eurasian Patent A61K 8/02; Nr 020907, A1. 28.02.2013.

[20] Mutalova, M.A., Babarikin, D. and Smirnova, G. (2018) Amorfus kalcija sāḷus saturoša kompozīcija ar osteoprotectīvu iedarbību. Latvijas Patents LV 15810 B, 20.05.2018.

[21] Close, B., Banister, K., Baumans, V., Bernoth, E.M., Bromage, N., Bunyan, J., Gregory, N., Hackbarth, H., Morton, D. and Warwick, C. (1997) Recommendation for Euthanasia of Experimental Animals. Part 2. DGXT of the European Commission. Laboratory Animals, 31, 1-32. https://doi.org/10.1258/002367797780600297

[22] AOAC Official Method 999.11 (1999) Lead, Cadmium, Copper, Iron and Zinc in Foods Atomic Absorption Spectrophotometry after Dry Ashing.

[23] Wienk, K.J.H., Marx, J.J.M., Lemmens, A.G., Brink, E.J., van der Meer, R. and Beynen, A.C. (1996) Mechanism Underlying the Inhibitory Effect of High Calcium Carbonate Intake on Iron Bioavailability from Ferrous Sulphate in Anaemic Rats. British Journal of Nutrition, 75, 109-120. https://doi.org/10.1079/BJN19960114

[24] Benkhedda, K., L’Abbé, M.R. and Cockell, K.A. (2010) Effect of Calcium on Iron Absorption in Women with Marginal Iron Status. British Journal of Nutrition, 103, 742-748. https://doi.org/10.1017/S0007114509992418

[25] Khammissa, R.A.G., et al. (2018) The Biological Activities of Vitamin D and Its Receptor in Relation to Calcium and Bone Homeostasis, Cancer, Immune and Cardiovascular Systems, Skin Biology, and Oral Health. BioMed Research International, 2018, Article ID: 9276380. https://doi.org/10.1155/2018/9276380

[26] Vaisman, N., Shaltiel, G., Daniely, M., Meiron, O.E., Shechter, A., Abrams, S.A., Niv, E., Shapira, Y. and Sagi, A. (2014) Increased Calcium Absorption from Synthetic Stable Amorphous Calcium Carbonate: Double-Blind Randomized Crossover Clinical Trial in Postmenopausal Women. Journal of Bone and Mineral Research, 29, 2203-2209. https://doi.org/10.1002/jbmr.2255 